\title{
Reflecting through Peshkin's I's
}

\author{
JONATHAN SAVAGE \\ Manchester Metropolitan University, UK
}

\begin{abstract}
Reflection is an appropriate way of accounting for professional practice and is a standard way in which one can 'become better acquainted with one's own story'. Defining 'subjectivity' as 'the quality of an investigator that affects the results of observational investigation', Peshkin highlights the requirement for any observer of, or participant in, educational events to be 'meaningfully attentive' to their own subjectivity as they conduct and reflect on their teaching and research activities. Using Peshkin's work as a model, this article considers the process by which the author identified a number of his own 'subjective I's'. From this process, key points are made for other teachers or researchers wanting to adapt this reflective method to their own work.
\end{abstract}

Key words

continuing professional development, ICT, intrinsic subjectivities, reflection, subjectivity, technology

\section{Introduction}

One of the artifices of evaluation is to portray individuals but to invest them (and their lives) with meanings derived from the projects in which we observe them - like clothing dolls. ... Instead of drawing a boundary around a project experience and reading individual lives within the context of the project, we need, just a little more often, to provide life experiences as contexts within which to understand educational projects. (Kushner, 1993, p. 39)

Kushner issues a provocative challenge that leads to a number of practical questions for us as teachers and researchers. A central point in his writing relates to the position of the teacher and researcher as an educational innovator or facilitator. How should they begin to understand their role and influence within the classroom? More fundamentally, how do they begin to piece together and understand educational events that occur within their classrooms? Where do the meanings that they ascribe to the lives of teachers and pupils come from as they analyse and evaluate the impact of the music education programmes that are delivered? Kushner's challenge to teachers and researchers is to seek, first, to 
194 INTERNATIONAL JOURNAL OF MUSIC EDUCATION 25(3)

understand education events through the context of one's own life experience. Kushner is well aware that such an approach is open to misunderstanding and the criticism of individualistic navel-gazing. But his writing boldly challenges educators to take more account of individuals and their life history:

We cannot assume that where the arts come into schools they do so in an unchanging way - that they are once and for all structured by artistic assumptions, priorities and beliefs. Programmes are subject to context as their meanings and significance are subsumed within personal lives. (Kusnher, 2000, p. 58)

Eisner picks up on this point in an empathetic manner in his discussion of the effect of the arts on the lives of artists. Starting from the premise that an ultimate aim of education might be 'to enable individuals to become the architects of their own education and through that process to continually reinvent themselves' (Eisner, 2002, p. 240), he states that:

The arts are among the resources through which individuals recreate themselves. The work of art is a process that culminates in a new art form. That art form is the recreation of the individual. Recreation is a form of re-creation. The arts are among the most powerful means of promoting re-creation. ... They are sources of deep enrichment for all of us. [his italics] (Eisner 2002, pp. 240-241)

Throughout my own teaching and research I have considered these viewpoints to be significant but have struggled to make sense of my own place within the educational projects and innovations that I have witnessed. Chief amongst these innovations have been the embracement of new technologies within my approaches to teaching music. I have written at length about many aspects of how new technologies transformed my approach to the teaching of musical composition and performance and have addressed issues such as individual pedagogies, curriculum development and the need for effective teaching training (Savage, 2004, 2005a, 2005b, 2005c; Savage \& Challis 2001a, 2001b). Yet in a recent review of these writings I have found myself to be peculiarly absent, particularly when faced by the challenge of Kushner and Eisner's thinking. Perhaps this has been because of personal wariness related to my perceptions of what constituted effective educational research and the role of oneself within it. Or perhaps I have caught my own disposition to invest individuals with meanings derived from projects rather than seeking to understand their inherent values and experiences in any meaningful way?

This article is a reflection on the adoption of a set of principles drawn from the work of Peshkin that allowed me to reflect on my work as a teacher researcher. It will be, I hope, an example of one way that others might find useful as they seek to make sense of the educational situations they are working through. Through adopting Peshkin's approach, I have come to realize that my personal understanding about the potential usefulness of new technologies as tools for music teaching and learning have their roots in foundational principles that have shaped my teaching and research career in fundamental ways. But before the work of Peshkin is introduced, a little background context is required.

\section{Background}

The first period of my career was the five years between 1996 and 2001 that I spent as a teacher, and then Head of Department, in two high schools in Suffolk, England. During the last four years of this period I was also registered as a part-time research student at the 
University of East Anglia (UEA) investigating the creative uses of new technologies within music education. The second period of my career has spanned the last six years. During this time I have been employed as a Senior Lecturer at the largest centre of teaching training in the north-west of England. It has been during this time that I completed my doctoral studies at the UEA and have recently begun a number of post-doctoral research projects.

From my current viewpoint, I find myself in the interesting position of being able to reflect over the initial part of my educational career and survey a period of considerable personal and educational change. Personal changes have included a major shift in employment and the completion of a long-term piece of educational research. Wider changes over this period have seen the growth and importance of technology within all spheres of education.

\section{Subjectivity and the reflective I}

I believe in the importance of teacher reflection as an appropriate way of accounting for professional practice (Schön, 1983, 1987; Watson \& Wilcox, 2000). Reflection has become a standard way in which teachers can 'become better acquainted with their own story' (Conle, 2000, p. 51), although I would share the view taken by Johnson that, 'the accounts teachers produce must be interrogated because those accounts are not 'out there' and fixed, waiting to be retold time and time again in the same manner' (Johnson, 2002, p. 21).

Defining 'subjectivity' as 'the quality of an investigator that affects the results of observational investigation' (Peshkin, 1988, p. 17), Peshkin highlights the requirement for any observer of, or participant in, educational events to be 'meaningfully attentive' (p. 17) to their own subjectivity as they conduct and reflect on their teaching and research activities. Peshkin describes subjectivity as a 'garment that cannot be removed' which has the capability to 'filter, skew, shape, block, transform, construe, and misconstrue what transpires from the outset of a research project to its culmination in a written statement' (Peshkin 1988, p. 17). His research goes onto to helpfully demonstrate this process through the identification of six subjective 'I's' that he perceived and reflected on during an extended piece of educational research at Riverview High School in California.

Peshkin describes each of these areas of his subjectivity in some detail. At a basic level I found it interesting to note where Peshkin thought each of these I's came from. Table 1 contains my micro-analysis of the foundations of Peshkin's I's drawn from the text of his article.

There are a number of important points here. First, the foundations for Peshkin's subjective I's are drawn from a range of sources, including:

- his own belief and value systems;

- his experiences of a particular environment or place;

- his ongoing experiences of life within the particular school;

- the wider community and the relationships that he, and other members of his family, established within that community.

Second, Peshkin sees these subjectives as falling into two main categories: 'Situational Subjectives' (Peshkin, 1988, p. 18) that change from place to place and are a subset of the whole array of what might be called 'Intrinsic Subjectives' that make up his reflective 'being'. For the purpose of this article, I will be focusing on 'intrinsic subjectivities' only. 
196 INTERNATIONAL JOURNAL OF MUSIC EDUCATION 25(3)

Table 1 An analysis of Peshkin's I's

\begin{tabular}{|c|c|c|}
\hline Peshkin's I's & Foundation & Key Quote \\
\hline Ethnic Maintenance I & $\begin{array}{l}\text { Pre-Riverview in his own } \\
\text { religious background and } \\
\text { beliefs. }\end{array}$ & $\begin{array}{l}\text { 'This is, of course, my } \\
\text { Jewish I, the one that } \\
\text { approves of my own reten- } \\
\text { tion of ethnicity.' (p. 18) }\end{array}$ \\
\hline Community-Maintenance I & $\begin{array}{l}\text { Discovered through a sense } \\
\text { of a place and its history. }\end{array}$ & $\begin{array}{l}\text { 'I felt this one in various } \\
\text { places, perhaps nowhere } \\
\text { more strongly than at } \\
\text { Mario's Snack Shop . . . } \\
\text { where an important sense } \\
\text { of community was perpetu- } \\
\text { ated every day.' (pp. 18-19) }\end{array}$ \\
\hline E-Pluribus-Unum I & $\begin{array}{l}\text { All the before, in-between, } \\
\text { and after class times at } \\
\text { Riverview High School. }\end{array}$ & $\begin{array}{l}\text { 'The visual impression of } \\
\text { the school captivated } \\
\text { me from the first time } \\
\text { I went there to the last. } \\
\text { I had never seen such } \\
\text { diversity; indeed, it did not } \\
\text { exist to the same degree } \\
\text { anywhere else in the com- } \\
\text { munity. I saw students } \\
\text { together in a way that } \\
\text { I found wonderful.' (p. 19) }\end{array}$ \\
\hline Justice-Seeking I & $\begin{array}{l}\text { Through observation of } \\
\text { Riverview's denigration and } \\
\text { inherent racism of } \\
\text { neighbouring communities. }\end{array}$ & $\begin{array}{l}\text { 'Riverview's denigration } \\
\text { distressed me ... . Although } \\
\text { feelings of distress } \\
\text { helped focus my enquiry - } \\
\text { a positive outcome - they } \\
\text { could make me defensive } \\
\text { in a way that would not } \\
\text { facilitate my analysis and } \\
\text { understanding.' (p. 19) }\end{array}$ \\
\hline Pedagogical-Meliorist I & $\begin{array}{l}\text { Reflection on teaching from } \\
\text { the back of a classroom. }\end{array}$ & $\begin{array}{l}\text { 'This emerged from } \\
\text { seeking ordinary-to-poor } \\
\text { instruction given to young- } \\
\text { sters who would suffer, } \\
\text { I imagined, as a conse- } \\
\text { quence of that instruction.' } \\
\text { (p.19) }\end{array}$ \\
\hline Non-research Human I & $\begin{array}{l}\text { The warmth of people's } \\
\text { reception and welcoming in } \\
\text { their community (including } \\
\text { that felt by his wider family). }\end{array}$ & $\begin{array}{l}\text { 'This softens one's judge } \\
\text { ment; its by product } \\
\text { is affection, which tends } \\
\text { to reduce the distance } \\
\text { between self and subjects } \\
\text { that scholars presume } \\
\text { is necessary to learning and } \\
\text { write about a person, place } \\
\text { or institution.' (p. 20) }\end{array}$ \\
\hline
\end{tabular}




\section{My intrinsic subjective I's}

Peshkin's approach allowed me to shed new light on my experiences as a teacher, the choices that I made whilst engaged in the role of 'teacher researcher' as well as illuminating the process of reflecting on these events through the written word. So using Peshkin's work as a model, I sought to reflect back on my career and ask myself whether I could identify any 'intrinsic subjective I's' of my own. In doing this, I hoped that I could, like Peshkin, 'create an illuminating, empowering personal statement that attunes me to where self and subject are intertwined' (Peshkin, 1988, p. 20).

Through this process of reflection, I identified the following intrinsic subjective I's that I believe have been an important influence on my work over the last 10 years. I have presented them in what I believe to be in as chronologically an order as I can manage, although the reader will quickly see that there are many overlapping and competing dimensions:

1. The Musically Conservative I

2. The Musically Radical I

3. The Pedagogically Inclusive I

4. The Technologically Enthusiastic I

5. The Artistically Appeasing I

A summary of my five intrinsic subjective I's is provided in Table 2.

\section{The musically conservative I}

This is, in a sense, the easiest ' $I$ ' for me to identify. It has existed for the longest and runs back in my memory to early childhood. It has its foundation in my training as a musician in the classical tradition, as a pianist from the age of five and a percussionist from the age of 11 . The strict disciplines of instrumental learning and performance practice are clearly etched in my memory alongside the immense enjoyment of being part of an orchestral group giving public performances, whether at the local civic hall in Camberley or under the grand auspice of a Henry Wood promenade concert at the Royal Albert Hall. I grew up to love the music of the western classical tradition and, in many senses as a teenager, to despise the music of popular traditions.

\section{The musically radical I}

My Musically Radical I was more difficult to identify. Strange as it seems now, this I seemed to have developed, to an extent, alongside the Musically Conservative I in my later teens. I remember an eccentric woodwind teacher at my sixth form college introducing me and my colleagues to a range of contemporary classical music. At first I did not understand the strange sounds that this music contained, but over the course of two years through participating in musical groups that played the music of Messiaen, Jolivet, Weill, Reich, Cage and others my musical palette began to broaden. This continued as a number of my friends began to compose experimental music of various types. As a percussionist, I was often called upon to perform these pieces and grew to love a broader palette of sound sources and textures.

But, like many performers, I was never that keen to engage in the act of composition itself. In contrast to my performing career, I had no formal tuition in composition beyond the stylistic pastiche exercises of Bach chorales and two-part inventions at ' $\mathrm{A}$ ' (advanced) level. It was only as my piano playing developed alongside my interest in jazz 
198 INTERNATIONAL JOURNAL OF MUSIC EDUCATION 25(3)

Table 2 My Intrinsic I's

\begin{tabular}{|c|c|c|}
\hline My I's & Foundation & Key idea \\
\hline Musically Conservative I & Early childhood. & $\begin{array}{l}\text { Strict definitions of musical } \\
\text { success (personally and } \\
\text { corporately); formalization } \\
\text { in the processes of musical } \\
\text { development. }\end{array}$ \\
\hline Musically Radical I & $\begin{array}{l}\text { Various, including } \\
\text { performance opportunities } \\
\text { during my musical studies } \\
\text { aged between } 16 \text { and } 18, \\
\text { the compositional work of } \\
\text { friends and my own jazz studies. }\end{array}$ & $\begin{array}{l}\text { New sounds and structures; } \\
\text { increasing palette of musical } \\
\text { possibilities; extension and } \\
\text { legitimizing of new path- } \\
\text { ways drawn from the } \\
\text { Musically Conservative I. }\end{array}$ \\
\hline Pedagogically Inclusive I & $\begin{array}{l}\text { I've found this difficult to } \\
\text { define, but it has led to a } \\
\text { dissatisfaction in traditional } \\
\text { music teaching methods as } \\
\text { being exclusive and my seeking } \\
\text { for more inclusive pedagogies. }\end{array}$ & $\begin{array}{l}\text { There are more ways into } \\
\text { music (by which I mean } \\
\text { the skills needed and the } \\
\text { experiences one can } \\
\text { obtain) than the way that } \\
\text { I experienced myself. }\end{array}$ \\
\hline Technologically Enthusiastic I & $\begin{array}{l}\text { Experience of music-making with } \\
\text { friends and others; kindled by } \\
\text { intrigue and awareness of } \\
\text { electroacoustic musical traditions } \\
\text { at UEA during my undergraduate } \\
\text { studies. }\end{array}$ & $\begin{array}{l}\text { Technologies provide new } \\
\text { ways to handle musical } \\
\text { materials. They can change } \\
\text { the whole nature of musical } \\
\text { practices at a fundamental } \\
\text { level. }\end{array}$ \\
\hline Artistically Appeasing I & $\begin{array}{l}\text { Observation of teaching and } \\
\text { my own teaching practice at } \\
\text { Stowmarket High School; } \\
\text { the quote from John Cage that } \\
\text { has dominated my teaching } \\
\text { of music over the last seven years. }\end{array}$ & $\begin{array}{l}\text { The process of making- } \\
\text { music can contain as much } \\
\text { of value as the final prod- } \\
\text { uct of that music-making. }\end{array}$ \\
\hline
\end{tabular}

that I began to learn to improvise and compose within this idiom. Ironically, the knowledge of music gained via my Musically Conservative I (particularly relating to harmony and counterpoint) put me in a strong position to learn about and understand the harmonic and melodic features of jazz. Like Sudnow (Sudnow, 1993, pp. 1-2), my technical abilities at the keyboard and knowledge of harmony facilitated my learning of the basics of jazz, but the ability to improvise freely at the keyboard became another matter altogether.

\section{The pedagogically inclusive I}

My experience taught me that there was only one way to learn about music. This was an exclusive and elitist activity available only to those that had sophisticated performance abilities and an understanding and appreciation of the western classical tradition. In my musical studies between the ages of 14 and 16 I was one of four pupils in a group studying for a public examination at ' $O$ ' (ordinary) level; my A level studies, post 16, at a local-sixth form college were in a much larger group that effectively alienated itself from the other students both geographically (through no fault of our own - the music department was some distance from the rest of the college) and socially (entirely through our own choice). We learnt, performed and socialized as an independent group. 
But at some point, which I find it hard to put my finger on, I realized that there had to be another way into music that was less exclusive and elitist. This did not happen as a result of my own teacher training experience. In the gap between this last sentence and the previous one I have spent over an hour reading through my old assignments and teaching practice materials from the initial teacher training studies. I can hardly find any references in them to any significant discussion, argument or belief statements that signal a change in my attitude from presenting an approach to musical study that was any different from the kind that I myself experienced and succeeded in. There is one exception to this bleak picture I will describe below.

I believe that the development of my Pedagogically Inclusive I is tied up intricately with the establishment of the Technologically Enthusiastic I.

\section{The technologically enthusiastic I}

As a high school pupil I remember shying away from computers and seeking to adopt more traditional approaches to working with pen, paper, manuscript paper and conventional instruments. The strength of my Musically Conservative I meant that I had strong views about the types of music that I preferred and led me to disparaging popular music and the ways in which it was produced. At that point it seemed to me to be far too easy to produce bland music of a particular type and, to this day, I still find it difficult to appreciate much of the popular music produced through the 1980 s.

However, when I left music college in 1989 my brother gave me his old computer and I began to use it as a MIDI sequencer. A friend and I fancied ourselves as songwriters and we made and recorded tracks with other vocalists. I used my musical notation skills to write arrangements for various people including the band that I played keyboards in.

This interest in computers and keyboards continued and developed throughout my time as an undergraduate at UEA. Although I did not see myself as a composer, and was also turning my back on my 'performer' identity at this time, I was obliged to take a composition unit in my first year of study. This unit constituted my first experience of formal composition teaching. Dennis Smalley taught our undergraduate class. He was the Director of the Electroacoustic Studios and I was aware that there was this wonderful (and seemingly secret) world of technologically enhanced composition work was going on upstairs. But I never got to make the journey upwards during that time.

It was as a young teacher at Stowmarket High School in Suffolk that I began to appreciate the importance that technology could play in widening access to music for a different type of pupil than myself. My experiences of using technology had always been to reinforce and consolidate my musical practices in light of my Musically Conservative I. My Musically Radical I had been nurtured and fed through my undergraduate studies and, to a degree, through my teaching qualification (a Postgraduate Certificate in Education (PGCE)). My Technologically Enthusiastic I spoke to me strongly during my early years of teaching and out of this melting pot I believe that my Pedagogically Inclusive I was born. Music education must be for all and not a few. I wanted to research and find ways to achieve this.

\section{The artistically appeasing I}

Out of the five subjective I's that I have sought to describe, this is the one that I have found most difficult to define. I am clear about where it came from. It came as a result of a lecture given during my PGCE course by a visiting lecturer, a community musician who challenged us with the words of John Cage:

Art, instead of being an object made by one person, is a process set in motion by a group of people. Art's socialised. It isn't someone saying something but a group of 


\section{INTERNATIONAL JOURNAL OF MUSIC EDUCATION 25(3)}

people doing things, giving everyone (including those involved) the opportunity to have experiences they would not otherwise have had. (Cage, 1968, p. 151)

Through this lecture my view of what counted as art or music was challenged at a fundamental level. Rather than focus solely on artistic objects, the lecturer asked us to value the processes by which these objects were formed as well as the experiences contained within these processes. In many ways my career to this point had been about faithfully recreating artistic objects for others to enjoy and little attention had been paid to enjoying the process of making or re-creating those objects. Yet I think that here are the seeds of my belief as a teacher that musical process is as important as musical product for our children. To be extremely bold (and I am struggling to even write this sentence), the process is even more important than the product, particularly when pupils have enjoyed the experiences contained within the process. This cuts right against everything that I was taught and valued for many years. My musicality was judged against performance outcomes and I succeeded as a musician because my musical 'products' were considered acceptable.

This is why I have called this final subjective I my Artistically Appeasing I. My dictionary gives three definitions for the word 'appease':

1. to bring to a state of peace or quiet;

2. to cause to subside;

3. to pacify or conciliate, especially: to buy off (an aggressor) by concessions usually at the sacrifice of principles.

When working within the classroom environment or the lecture theatre, I feel that I am appeasing many elements of my Musically Conservative I, bringing them to a state of peace or quiet. But this is not in the sense of buying off or giving concessions. There have been no concessions given or principles sacrificed. My Artistically Appeasing I believes deeply in the genuine artistic practice of young people's classroom work at a philosophical, aesthetic and educational level. The ideals and beliefs of the Musically Conservative I are still present. I still love the music of the western classical tradition and have sought to pass on that passion to my pupils in various ways. But I believe that the process by which these convictions have been appeased and, in a sense, broadened has made my approach to teaching more inclusive and tolerant of the various pathways by which pupils can come to know and understand musical knowledge and develop personal ways of expression.

\section{Conclusion}

What has the process of reflecting on my intrinsic I's taught me? Ultimately, if I want to understand any attempts towards innovative practice in music education, it is essential for me to find ways to represent and understand my own subjectivities. It is not enough to be able to write a biographical account of their work. I find myself agreeing with Kushner (Kushner, 1993, p. 39) that in order for true educational changes to occur both my pupils and my own life experiences should become the context from which educational understanding will emerge.

Whilst I recognize the importance of reflecting on my own subjectivities, perhaps the principles should be extended to our pupils? As teachers, we learn to value pupils' creative ideas, their input into discussions, their scepticism about our plans, their moans and complaints 
about curriculum tasks or various pieces of technology and their joys at discovering solutions to artistic problems. All of these observations or comments allow us to understand their responses to a particular music programme at a deeper level. Nurturing the pupil's voice is of prime importance within the teaching and research process. Perhaps a 'Pupil Centred I' ought to be my sixth subjective I. Howard Gardner described it like this:

We must place ourselves inside the heads of our students and try to understand as far as pos.e sources and strengths of their conceptions. (Gardner, 1991, p. 253

\section{Implications}

The process of reflection described above is, in one sense, personal and idiosyncratic. But I believe that there are implications and potential benefits for all teachers. These are summarized briefly below.

\section{Understanding your own subjectivities is the root of educational understanding}

Peshkin's subjective I's are one useful strategy for helping us understand the root values that underpin our fundamental conceptions of education and their outworking through our practice. His notion of a 'situational $I$ ' extends this metaphor into particular times and places and is equally valuable. But as a first step, seeking an enhanced understanding of your own subjective I's can be tremendously enlightening as you seek to reflect on your own professional practice.

\section{Promote reflective strategies at all stages of teaching - from initial teacher education throughout continuing professional development}

Systematic reflection is central to initial teacher education in the UK. Similarly, for certain moments (e.g. a particular collaborative arts event), a process of performance management or a course of study, teachers are required to provide evidence of their ongoing, self-evaluation as part of their professional development. Whilst many of these triggers for reflection could be conceptualized as 'external', Peshkin argues for the promotion of 'internal' reflective thinking that underpins and has benefit for all stages of teaching. In my case, an external trigger (a PhD course of study) was the prompt I needed. But I have seen the benefit of continuing, internal reflective practice as a way of making sense of my own teaching and research activities.

\section{Seek to counteract the 'busyness' culture and allow space for reflection}

As teachers and researchers we are faced with a range of competing demands on our energy and time. It is often too easy to prioritize badly and dwell on the insignificant at the expense of the significant. In my teaching, I quickly realized that the only way that I was going to develop a clear understanding of the benefits of using new technologies within music education was to consciously and deliberately place my own, and my pupils', experiences at the centre of any educational and research agenda. It is vital that we do not become too busy and the space for this kind of reflection is lost. 
202 INTERNATIONAL JOURNAL OF MUSIC EDUCATION 25(3)

\section{Nurture your pupils' voices and their perceptions of your teaching}

Finally, who is the best judge of your teaching? Who is the sharpest critic of your research findings? Pupils are in a unique place to comment on both these activities. Recent research by Finney has stressed the importance of the pupil voice in initial teacher education. In his fascinating account of an alternative vision for music education (Finney, 2006), he examines the relationships between teachers and learners and how this can promote musical learning when it is characterized by a healthy connection, interest and concern amongst teachers and learners. Finney challenges us to consider where musical skills, understanding and knowledge come from. Do they come from external, nation-wide programmes of curriculum reform? No. Music, in this sense, is caught not taught. Or, in Finney's words:

Skills, knowledge and understanding, in this instant, are imminent to the life of the learner, the teacher and the subject. (Finney, 2006, p. 4)

This is the ultimate goal of all reflective practice. As we struggle to formulate and implement models of music education of this type within schools, we must ensure that they are underpinned by strong models of reflective practice that empower quality teaching and learning.

\section{References}

Cage, J. (1968). Silence. Cambridge, MA: M.I.T.

Conle, C. (2000). Narrative inquiry: Research tool and medium for professional development. European Journal of Teacher Education, 23(1), 49-63.

Department for Education and Skills (DfES) (2002). Pupils' and teachers' perceptions of ICT in the home, school and community. London, DfES.

Eisner, E. (2002). The arts and the creation of mind. New Haven \& London: Yale University Press.

Finney, J. (2006). Richer learning, poetic thinking and music understanding. NAME Magazine, $6(18), 2-4$.

Gardner, H. (1991). The unschooled mind. New York: Basic Books.

Johnson, G. C. (2002). Taking up a post-personal position in reflective practice: One teacher's accounts. Reflective Practice, 3(1),21-38.

Kushner, S. (1993). One in a million? The individual at the centre of quality control. In J. Elliott (Ed.), Reconstructing teacher education: Teacher development (pp. 39-50). London, The Falmer Press.

Kushner, S. (2000). Personalising evaluation. London, Sage.

Peshkin, A. (1988). In search of subjectivity - one's own. Educational Researcher, 17(7), 17-22.

Savage, J. (2004). Re-imagining music education for the 21st century: Innovative approaches to teaching, learning and research with ICT. Unpublished PhD thesis, University of East Anglia, UK.

Savage, J. (2005a). Information communications technologies as a tool for re-imagining music education in the 21 st century. International Journal of Education \& the Arts, 6(2). Retrieved 24 August 2007 from ijea.asu.edu/v6n2/

Savage, J. (2005b). Sound2Picture: Developing compositional pedagogies from the sound designer's world. Music Education Research, 7(3), 331-348.

Savage, J. (2005c). Working towards a theory for music technologies in the classroom: How pupils engage with and organise sounds with new technologies. British Journal of Music Education, 22(2), 167-180.

Savage, J. \& Challis, M. (2001a). A digital arts curriculum? Practical ways forward. Music Education Research, 4(1), 7-24.

Savage, J. \& Challis, M. (2001b). Dunwich revisited: Collaborative composition and performance with new technologies. British Journal of Music Education, 18(2), 139-49.

Schön, D. (1983). The reflective practitioner: How professionals think in action. New York: Basic Books.

Schön, D. (1987). Educating the reflective practitioner: Toward a new design for teaching and learning in the professions. San Francisco, CA: Jossey-Bass.

Sudnow, D. (1993) Ways of the hand: The organization of improvised conduct. Cambridge, MA: M.I.T.

Watson, J. S. \& Wilcox, S. (2000). 'Reading for understanding: Methods of reflecting on practice. Reflective Practice, 1(1), 57-67. 
Jonathan Savage is a Senior Lecturer in Music Education at the Institute of Education, Manchester Metropolitan University. Until 2001, he was Head of Music at Debenham High School, an 11-16 comprehensive school in rural Suffolk in the east of England. His main research interests lie in the field of developing innovative uses of new technologies within the music curriculum, particularly in promoting new approaches to composition. He is Managing Director of UCan.tv (www.ucan.tv), a not-for-profit company that produces engaging educational software and hardware including Sound2Game (www.sound2game.net) and Hand2Hand (www.hand2hand.co.uk).

Address: Institute of Education, Manchester Metropolitan University, 799 Wilmslow Road, Didsbury, Manchester M20 2RR, UK. [email: j.savage@mmu.ac.uk]

\section{Abstracts}

\section{Réflexion à travers le 'je' de Peshkin}

La réflexion est une manière appropriée de comptabiliser les pratiques professionnelles et est une manière standard avec laquelle on peut 'se familiariser avec sa propre histoire'. En définissant la 'subjectivité' comme 'la qualité d'un enquêteur qui affecte les résultats d'une enquête observatrice'. Peshkin accentue la nécessité d'être 'significativement attentif' à sa propre subjectivité pendant la conduite et la réflexion sur son propre enseignement et ses propres activités de recherche. En utilisant le travail de Peshkin comme modèle, ce papier médite sur le processus avec lequel l'auteur identifie un certain nombre de ses 'je' subjectifs. A partir de ce processus, des points clés sont dégagés pour d'autres enseignants et chercheurs qui veulent adapter cette méthode réflexive à leur propre travail.

\section{Reflektieren über Peshkin's Ich's}

Reflektion ist eine angebrachte Weise die berufliche Tätigkeit zu überprüfen und ein üblicher Weg besser mit der eigenen Geschichte vertraut zu werden. Subjektivität wird definiert als die Qualität eines Forschers, welche sich auf die Resultate beobachteter Untersuchungen auswirkt, Peshkin's hebt die Bedeutung hervor, wie aufmerksam man auf seine eigenen Subjektivität sein soll, da diese das Lernen und die Forschung gestaltet und widerspiegelt. Peshkin's Arbeit als Vorbild benutzend, befasst sich dieser Bericht mit dem Prozess wie der Autor sich in verschiedenen Ich's wieder findet. Schlüsselpunkte werden aus dem Prozess aufgezeigt, um anderen Lehrern und Forschern die es wünschen, zu ermöglichen, diese reflektive Methode in ihrer eigenen Arbeit anzuwenden.

\section{Reflexionar mediante los "yoes" de Peshkin}

La reflexión es una manera apropiada de explicar la práctica profesional y es un medio estándar por el que uno puede "familiarizarse con su propia historia". Al definir "subjetividad" como "la cualidad de un investigador que afecta los resultados de la investigación observacional", Peshkin subraya el requerimiento de estar "significativamente atento" a la propia subjetividad al llevar a cabo actividades de enseñanza e investigación, y al reflexionar sobre ellas. Este artículo considera el proceso por el que el autor identificó algunos de sus propios "yoes subjetivos", usando el trabajo de Peshkin como modelo. A partir de dicho proceso, se sugieren puntos clave para otros profesores o investigadores que quieran adaptar este método reflexivo a su propio trabajo. 
